\title{
Revising Alfred, Lord Tennyson: A Closer Look at Two Color Line Stories "The Wife of His Youth" and "Cecily's Dream" by Charles W. Chesnutt
}

Christopher E. Koy

University of South Bohemia, College of Education, English Department, Jeronýmova 10, 37115 České Budějovice, Czech Republic https://orcid.org/0000-0002-2299-198X koy@pf.jcu.cz

This article explores an African American writer's revision of a famous English poet Tennyson whose versified medieval portrait of the Arthurian legend appears in Idylls of the King as well as other poems. The Wife of His Youth and Other Stories of the Color Line (1899), a story collection by African American author Charles Chesnutt (1858-1932), addresses parameters contextualized in the aftermath of slavery such as esthetic notions of beauty tied to whiteness and intra-racial inequality. The final failure of two protagonists, a man and a woman, to fulfill their romantic aspirations of whiteness connects the collection's titular story to "Cecily's Dream." In addition to the color-line theme, however, Chesnutt is motivated to refer to the poetry of Alfred, Lord Tennyson (1809-1892), including moments in which chivalric codes of honor, whiteness and flawed courtly love are idealized. Tennyson's parabolic poems provide Chesnutt's intertextual scheme to engage the implied reader by renewing, transforming and also subverting the motif of courtly love in these Arthurian idylls.

Keywords: English poetry / Tennyson, Alfred / African American literature / intertextuality / Chesnutt, Charles W. / Arthurian legends / chivalry / courtly love

\section{Introduction}

The constructive, dialectical relationship between literary texts reflects a significant and diachronic need to relate to mythical foundations of culture. Rewriting historical and canonical texts has been a persistent pattern in Western literary traditions: looking backwards at 
myth and legends of the distant past has motivated authors since the ancient Greeks. Tennyson's and Chesnutt's self-reflective impulses reveal themselves to be in a dialogue with many other canonical texts. In spite of his humble origins, Charles W. Chesnutt was particularly aware of cultural trends and literary taste among his American readership. The extraordinary popularity of Tennyson's Idylls of the King has been explained by John D. Rosenberg: "Arthur underwent a revival in the nineteenth century, particularly during the reign of Victoria, because England had become so quickly and so radically un-Arthurian" (Rosenberg 149), and in Camelot Regained: The Arthurian Revival and Tennyson 1800-1844, Roger Simpson squarely places the revival on the popular impact of Tennyson's poetic successes. Tennyson's popularity may be attributed to how he artistically versified courtly love accompanied by adventure, danger and violence while toning down acts of sexual transgression. ${ }^{1}$ Furthermore, his popularity has been linked by what another critic calls "his excellence in the arts of sumptuous coziness" (Tucker 703). ${ }^{2}$ Some contemporaries criticized Tennyson's idylls for being too tame. A. C. Swinburne for instance "condemned what he felt was the reduction of Sir Thomas Malory's virile tales of chivalry to a sordid domestic quarrel [...] a case for divorce court than for poetry" (cited in Gilbert 864). On the other hand, Pelleas and Ettarre seems to me anything but tame. Tennyson's versions underscore the "false women" as culprits bringing about the dissipation of Arthur's Camelot. Charles W. Chesnutt sought to propose another perspective when revising Tennyson's Arthurian legends. Chesnutt took an altogether different angle for his fiction than just writing belles-lettres. Decades earlier while still living in the former Confederate state of North Carolina, the light-skinned Black author expressed his intentions in a journal entry, dated May 29, 1879:

If I do write, I shall write for a purpose, a high, holy purpose, and this will inspire me to greater effort. The object of my writings would be not so much the elevation of the colored people as the elevation of the whites. [...] This work is of a twofold character. The negro's part is to prepare himself for social

${ }^{1}$ This revival in the nineteenth century came well after the popularity of Arthurian courtly romances had declined during the Renaissance authors such as Miguel de Cervantes Saavedra (1547-1616) efficaciously lampooned not just epic chivalric romances but also their readers in his masterpiece Don Quixote de la Mancha (1615).

${ }^{2}$ The moral code particularly attracting Charles W. Chesnutt concerns specifically to how men-or rather gentlemen - are to ethically behave towards women rather than, for instance, the expectations of courageous behavior of a knight in combat or such noble virtues as generosity or obedience to authority. 
recognition and quality; and it is the province of literature to open the way for him to get it - to accustom the public mind to the idea: and while amusing them to lead them on imperceptibly, unconsciously step by step to the desired state of feeling. (Chesnutt, The Journals 139-140)

In other words, this fiction serves as a mirror of self-reflection for his implied white readers. In the aftermath of the Civil War and Reconstruction, lynching and the reduction of civil rights for blacks became commonplace. Chesnutt established his fiction as an agent of change to lift up white Americans' behavior by entertaining white addressees while it only adumbrates the idea of racial social justice. Chesnutt's stories do not employ vituperative discourse common to protest fiction to expose evil practices nor do they fervidly expound the case for equality. Despite setbacks such as the Supreme Court's Plessy vs. Fergusson landmark decision legalizing racioal segregation as well as the relapse regarding African American franchise established in the Fifteenth Amendment, the pronouncement in Chesnutt's fiction comes out rather elusively.

Herbert F. Tucker points out that "epic poetry, we are told by a firmly consensual line of Romantic theorists from J. C. Herder to Northrop Frye, teaches a nation its traditions. Epic tells a culturemaking story, which both embodies in the incidents it narrates, and enacts in its narrative practices, values that bind a people in a common identity" (Tucker 701). Retelling myths reinforces a linear destiny that expels supernatural destiny. For the last fifty years, criticism has reformulated the notion of literary history as a dynamic interplay of texts, as texts which "talk" to each other. J. Hillis Miller characterizes literary works as "inhibited [...] by a long chain of parasitical presences, echoes, allusions, guests, ghosts of previous texts" (Miller 446). This paper aims to show how two stories by Chesnutt are germane to and partially derived from plots and figures of Tennyson's poetry by analyzing the intertextual significance of the reworked medieval materials in Tennyson which Chesnutt in turn revised in his frequently anthologized short story "The Wife of his Youth" as well as his lesserknown story "Cicely's Dream." ${ }^{3}$ The interpretation attempts a layered,

${ }^{3}$ The number of scholars exploring "The Wife of his Youth," which names and cites Tennyson, is plentiful while no scholar has given any attention to the literary reverberations of Tennyson in "Cicely's Dream." For example, in his book-length study on Chesnutt's short fiction, Henry Wonham does not analyze "Cicely's Dream" at all, and neither Sollors nor Bone refer to Tennyson's influence on "Cicely's Dream" in their lengthier examinations of Chesnutt's prose (see Sollors; Bone). 
textured approach to the two stories to make new connections and a more vibrant discussion between white Victorian culture represented by Tennyson and the African American culture during Reconstruction represented by Chesnutt. The power of shared referencing embedded in Chesnutt's story "The Wife of his Youth" resonated with the American readership very successfully. Published in The Atlantic Monthly in 1898, the remarkable reception of "The Wife of his Youth" (also published in French as "L'épouse de sa Jeunesse") largely aided in accommodating the publication of Chesnutt's story collection entitled The Wife of His Youth and Other Stories of the Color Line (1899).

Tennyson's twelve idylls were published over four decades of the nineteenth century and primarily based on Geoffrey of Monmouth's The History of the Kings of Britain written in Latin, Sir Thomas Malory's Le Morte Darthur written in Middle English and the Mabinogion, originally composed in Middle Welsh, the last of which Tennyson had read in modern English translation. Tennyson's commitment to rendering Arthurian romance into poetic form spanned nearly his entire adult life. In highly accessible poetic form, Tennyson records courtly love as a paradox underlying the system of the chivalric code. The Arthurian Cycle was nostalgically sought after in Victorian England and the United States where readers found Malory's Middle English "with its archaic language and style of narration too daunting" (Lambdin 13). Fiction writers charted the esteem for the Arthurian revival and responded with many versions ${ }^{4}$ just as the myth of King Arthur has been perpetually recycled in many languages throughout Europe during the last millennium.

\section{"The Wife of His Youth"-a Revision of Courtly Love}

Using direct evocations of Tennyson's poetry, the protagonist in Chesnutt's story, an upper-class African American named Mr. Ryder, revels in the ideals of chivalric virtue: stability, chastity and loyalty. In "The Wife of His Youth," the social circles of upper crust African

\footnotetext{
${ }^{4}$ Some American authors wrote popular versions: Sidney Lanier's The Boy's King Arthur (1880), the novel A Connecticut Yankee in King Arthur's Court (1889) by Mark Twain (both Southerners), assorted poetry by, for example, Elizabeth Stoddard, "Before the Mirror" (1895), Edgar Lee Masters, "Ballad of Launcelot and Elaine" and "Death of Launcelot" (both 1916), Edward A. Robinson's "Merlin" (1917) and Edna St. Vincent Millay's "Elaine" (1921). Modernist African American novelists who later made use of parodic mimicry on Arthurian myths include Ralph Ellison, Invisible Man (1952), Ishmael Reed, The Last Days of Louisiana Red (1974) and Paule Marshall, The Fisher King (2000).
} 
Americans that Mr. Ryder leads emulate the decorum, good-graces and high principles of the Victorian Age where love is regarded as omnium fons et origo honorum and fully compatible with marriage, the very flowering of civilization, just as it was apprehended in the code of chivalry. With little room for liberal progressivism, Mr. Ryder, a member of the highest echelon of black people in northern United States, invokes an ethos of a distinguished social order for society that his African American followers unreservedly trust:

He had observed of late a growing liberality, almost a laxity, in social manners, even among members of his own set, and had several times been forced to meet in a social way persons whose complexities and callings in life were hardly up to the standard which he considered proper for the society to maintain. (Chesnutt, Conjure 106)

Mr. Ryder perceives a dissolution of the social order in his time. Like King Arthur, Mr. Ryder aims to put order into the chaotic post-conflict society. Significantly, social standing and skin pigmentation were intertwined in Ryder's mind as well as those of "his own set"s whereby, in this American setting, discrimination leads to new social opportunities. However, like the knights of the Round Table, Mr. Ryder's followers fall short in resembling the "stainless man" (Tennyson 134), and like King Arthur, Mr. Ryder tutors his society to follow strict exclusionary principles which hardly any can keep. As Aidan Day affirms, "the ideal and idealistic Arthur sometimes offers both a moral perspective and a portentously self-righteous way of articulating it" (Day 189), a criticism which equally applies to the smug Mr. Ryder. In Arthurian epics the development of the proper inner attitude is central to the mastery of courtly behavior. In mimicking Southern elite whites who share pretensions of chivalry, Chesnutt ultimately has his caricature of this subclass of the haute black bourgeoisie, Mr. Ryder, alter this behavior outwardly.

Preparing for his own high-society engagement ball, Mr. Ryder hosts light-toned African American guests at his elegant home filled with ornate works of art exhibiting his conspicuous consumption and status hunting. Mr. Ryder intends to set an example to society about how to live and conduct oneself as elite members of civilized society. Yet his art has less to do with its intrinsic value or with his fine taste than the opulence his art collection exhibits.

${ }^{5}$ Akin to Mr. Ryder's "light mulatto" complexion, King Arthur "is fair / Beyond the race of Britons and of men" (Tennyson 22) in "The Coming of Arthur" even though his alleged parents Uther and Ygerne are dark-eyed and dark-haired. 
His search for an exquisite poem which might aptly convey his love leads him to Alfred, Lord Tennyson, particularly his images of Guinevere, King Arthur's stunning wife, and his record of her passionate adultery with the darker Lancelot. Mr. Ryder echoes both male characters: in his social climb upwards, his behavior reflects Arthur's ascetic ways, though after meeting the near-white and highly treasured widow Mrs. Molly Dixon, Ryder may appear transformed into a sensuous Lancelot. Expressly looking for a love poem in a thick "volume of Tennyson-his favorite poet-fortifying himself with apt quotations" (Chesnutt, Conjure 106) for his wedding proposal, Mr. Ryder recites parts of poems focused on beauty defined by Tennyson as pale, fair or white. This focus appears rather ironic for an African American yet is tellingly appropriate for the "Blue Vein Society" where an "envious outsider made the suggestion that no one was eligible for membership who was not white enough to show blue veins" (103). Mr. Ryder aspires to the problematic ethos of courtly love, the idolatry of whiteness and accordingly the condescension of people of darker hues.

An early Tennyson poem, "A Dream of Fair Women" (1842) is read aloud by Mr. Ryder along with the poem "Margaret," which among other features links whiteness to the uppermost ideals of beauty. "A Dream of Fair Women” features the Ptolemaic Queen of African Egypt, Cleopatra. As a devious Egyptian leader with a decidedly Greek education and possessing Greek family roots, ${ }^{6}$ the unmarried Cleopatra's political intrigues and intimate relations with Julius Caesar, bearing him a son, and then with the servile Mark Antony, with whom she had three children, appeared too lascivious for Mr. Ryder's engagement ball. The poems he had just read "would not do" (Chesnutt, Conjure 107). Werner Sollors makes note of the volume that Mr. Ryder likely reads from when reciting out loud the opening lines of "A Dream of Fair Women," that "it was exactly of that page that Cleopatra's image was reproduced, above the poem's title" and that "Tennyson complained about [the pre-Raphaelite illustrator John Everett] Millais' choice to make Cleopatra a Mulatto" (Sollors 230), further underscoring how this aesthetic preference for whiteness is imbricated in Tennyson's multifaceted ideology. As a representation in Ryder's fantasy of the perfect embodiment of virtuous love, Mrs. Dixon was "of lively disposition and buxom build. So he ran over the leaves until his eye rested on the description of Queen Guinevere" (Chesnutt, Conjure 107). Like King Arthur, he presumes that her exterior beauty indicates virtuous

\footnotetext{
${ }^{6}$ For more details regarding the American reception of Cleopatra's color, see Maier.
} 
exquisiteness; given his views on assimilation into the white race, Molly Dixon may be but a means and not an end to Mr. Ryder. Nevertheless, Ryder recognizes that in both cases, Cleopatra and Guinevere fall short on desirable virtues like loyalty or chastity.

Up to that point, the conservative and well-mattered gentleman was said to have been avoiding marriage for decades, echoing Lancelot's sentiments on lifelong bachelorhood. Yet like the charming and beautiful Guinevere for young Arthur, the wealthy Molly Dixon

had won Mr. Ryder's heart. She possessed many attractive qualities. She was much younger than he; in fact, he was old enough to have been her father [...]. She was whiter than he, and better educated. She had moved in the best colored society of the country, at Washington. (Chesnutt, Conjure 105)

Since Mrs. Dixon's husband had died and left the twenty-five-year old socialite wealthy, nothing blocks Ryder from rising significantly higher in society, as marriage with her would greatly increase his purse. As a man "moving white," Mr. Ryder confirms racial conventions of the "Blue Vein Society" as well as the ideology, as Ryder understood them, versified by the esteemed British Poet Laureate. "The Wife of His Youth" traces how Mr. Ryder adroitly manages "the complexities of attempting to balance love, marriage, racial responsibility, social mobility and the burden of history" (Duncan xxi). Ryder conveys his haughty racial ideologies clearly enough: "we people of mixed blood are ground between the upper and the nether millstone. Our fate lies between absorption by the white race and extinction in the black." (Chesnutt, Conjure 104) Like a utilitarian opportunist, he argues for the abandonment of darker blacks while accentuating his vanity with a poetry reading explicitly preferring "light" women, obviously derogatory and irresponsible behavior. Moreover, in advocating the Blue Veins to consent to a limiting identity imposed on them, Ryder's ethics requires some African Americans to accept the delusion that they are other than they really are, to adopt haughty aristocratic behavior that was anathema to characteristics of African Americans, most of whom were only recently emancipated. At the same time, Ryder invokes President Abraham Lincoln's Second Inaugural Address: "With malice towards none, with charity for all, we must do the best we can for ourselves and those who are to follow us. Self-preservation is the first law of nature." (Chesnutt, Conjure 106) Ryder's second sentence hardly arouses the Christian beneficence Lincoln had intended to inspire. Indeed, his prediction of the extermination of the black race echoes Arthurian eschatology, the 
ultimate defeat of the ideals of Camelot. Mr. Ryder finds verse conveying his longings for ladylike beauty and the explicit color idyllic in Tennyson's poem "Margaret" (1833) which Ryder recites:

\author{
O sweet pale Margaret, \\ $\mathrm{O}$ rare pale Margaret, \\ What lit your eyes with tearful power, \\ Like moonlight on a falling shower? \\ Who lent you, love, your mortal dower \\ Of pensive thought and aspect pale, \\ Your melancholy sweet and frail \\ As perfume of the cuckoo-flower? (Chesnutt, Conjure 107)
}

As he searches onward in the poetry of Tennyson, Ryder rummages from the royal African Cleopatra to Arthur's wife Queen Guinevere to the pale Margaret. Chesnutt's implied white readers might wonder if this poetry reading is really being seriously considered as appropriate among African Americans, or if Chesnutt is just mockingly "pulling their leg." However, Ryder's stimulating reading of Tennyson's seductively enchanting Margaret gets interrupted by the visit of a dark black elderly woman who stops by Mr. Ryder's front porch. He lowers his thick Tennyson volume to assist the poorly-attired black elderly lady.

Born as a slave in Missouri, Eliza Jane Taylor tells Mr. Ryder that she is in great need of assistance. She then narrates back in time to earlier events of love, self-sacrifice and abiding loyalty. Many years earlier, she had alerted her free-born mulatto husband to escape from enslavement when she learned her owner planned to illegally sell him to a trader: "W'en Sam come home f m de fiel' dat night, I tole him 'bout ole marse gwine steal 'im an' Sam run away [...]. Ole marse had heerd dat I warned Sam, so he had me whip' an' sol' down de ribber." (Chesnutt, Conjure 109) Her husband escaped safely to the free north, while she, in forced exile, was victimized by slaveholders in the deep South, their fates differing in the starkest contrast conceivable. Consequently, Eliza Jane has not seen her husband for some twenty-five years. While her displacement is central to the slave experience, it continues well after the Thirteenth Amendment abolished slavery in 1865.

Nevertheless, her ascetic patience facilitates her quest to locate her husband long after the war. After this analepsis, Eliza Jane's narrative becomes even more astounding: "I's be'n lookin' for 'im eber sence [...]. I's be'n ter Noo Orleens, an' Atlanty, an' Charleston, an' Richmon'; an' w'en I'd be'n all ober de Souf I come ter de Norf." (Chesnutt, 
Conjure 109) On the day of his engagement ball, Eliza Jane confidently maintains her faith in her husband's loyalty: "and I knows he's be'n lookin' fer me. Fer he sot a heap er sto' by me, Sam did." (Chesnutt, Conjure 109) In her quest, reclamation and restoration are her ultimate objectives much like grail seekers of Tennyson's Idylls. She humbly asks the benevolent Mr. Ryder if he happened to be acquainted with her husband, Sam Taylor. Mr. Ryder refers her to the fact that the marriages during slavery were not legally recognized and freed slaves were required by law to re-marry before a court. Since she had not remarried him, Sam might have married another woman. Eliza Jane vehemently protests: “'No, indeed, suh,' she replied, 'Sam ain' dat kin' er man. He wuz good ter me, Sam wuz.”' (Chesnutt, Conjure 110) Replicating mystical visions of supernatural events in Tennyson's Idylls, Eliza Jane Taylor perseveres in seeking her husband because of voodoo prophesy and dreams, both of which she discloses to Mr. Ryder: "He ain' dead. De signs an' de tokens tells me. I dremp three nights runnin' on'y dis las' week dat I foun' him." (Chesnutt, Conjure 110) She is predestined to find him. Mr. Ryder asks the kind, unpretentious woman for her address and would soon contact her after looking into the matter. In spite of the injustice of her enslavement, whipping and her terrible treatment after being sold down the river, the impecunious Eliza Jane shows no indication of bitterness. To sum up, Chesnutt sentimentally paints Eliza Jane as a saint.

Mr. Ryder's struggle in modifying his racial and social principles is not described in the story, but it must have been distressful. He reflects upon his own status and acquires a new self-awareness and knowledge of his "sins," including neglect of his vows of marriage. The abiding loyalty of Eliza Jane has transformed Ryder inwardly. Clearly, his longacquired decrepit principles were not attuned with the characteristics of Eliza Jane's heroic deeds. Reminded that his freedom is ultimately not of his own making, he recognizes that his wife's brave and well-timed warning decades ago enabled his escape north as well as his impressive social ascent. What is more, Mr. Ryder has been deceitful about his own origins and identity ${ }^{7}$ - not merely regarding his fortuitous escape from enslavement but additionally his antebellum marriage. Like Arthur, Ryder's origins were never clear to the public. ${ }^{8}$ The plot skips

${ }^{7}$ Mr. Ryder's acquired full name while living in the North is never revealed; only his full original name is referred to by Eliza Jane Taylor: Sam Taylor.

${ }^{8}$ In The Coming of Arthur Guinevere's father King Leonogran is deeply troubled by doubts about Arthur's legitimacy to be king. It remains unclear who Arthur's father really was. 
from Eliza Jane's departure to the scene quite a few hours later at the formal ball, a large gap of unaccounted time.

At his assembled engagement ball, Mr. Ryder is expected to ask the charming Mrs. Dixon for her hand in marriage to escape his lonely bachelorhood, though Mr. Ryder does not recite Alfred, Lord Tennyson's poems as originally planned. Instead, he decides to come clean: after retelling Eliza Jane's slave narrative and her multiple-decade-long pursuit of her husband, Mr. Ryder eloquently narrates the life of Eliza Jane's husband, whose marriage to a slave was legally invalid and whose ascent in society kept him safe from recognition. Ryder presciently asks guests at the ball this question: "What would he do, or rather, what ought he to do, in such a crisis of a lifetime?" (Chesnutt, Conjure 113) Compelling his guests to take active accountability by deciding an honorable choice with a public answer, the ultimately transient nature of medieval ideals of the Blue Veins are democratically corrected, replacing Tennyson with a slave narrative plus the fêted lines of Polonius to his son Laertes from Hamlet.

This above all, to thine own self be true,

And it must follow, as the night the day,

Thou canst not then be false to any man. (Shakespeare 22)

Mr. Ryder abandons his ideologies as Eliza Jane thwarts his ardent desire for whiteness by waking him up to the true meaning of a virtuous woman. Under the catalytic effect of a deus ex machina, her sudden appearance triggers the anagnorisis that he is of ordinary folk, moreover that he is already married to a devoted, virtuous wife. His epiphany regarding her steadfast integrity dramatizes the ending of his racism as well as his appreciation of true virtue. The intensity of Mr. Ryder's sensitive reorientation is exacerbated by the timing: he encounters Eliza Jane just as he is about to become engaged to another woman. Rejecting that an African American would imitate the disgraceful and pernicious influence of racism by discarding one's true mate for whiteness or fleeting youth and beauty, Chesnutt's protagonist abruptly deserts fashionable Tennyson in favor of Shakespeare, thereby overcoming what Henry Wonham postulates most Blue Vein members engage in, namely the consciously unsympathetic repression of the history of slavery (Wonham 57). Mr. Ryder has precipitously fled to the North but with Eliza Jane's resurfacing, his mind has come full circle and returned to his original self and to true love, even speaking in African American Vernacular English at the ball. Mr. Ryder fittingly orchestrates his fellow Blue Veins to favor a righteous reso- 
lution in his "crisis of a lifetime," in the court of public opinion. By means of an almost homiletic nature, Ryder quotes Polonius's "advice" expressed in an imperative, "to thine own self be true," thereby urging the Blue Veins to decide for social and racial solidarity and genuine honor.

Because Eliza Jane Taylor lived as the embodiment of intractable virtue over the course of decades, Mr. Ryder is compelled to remarry her. While his original principles privileged Mrs. Molly Dixon's whiteness as the essence of society's shared ideals of virtuous love and beauty (Tennyson), Ryder's trothplight is remedied by Eliza Jane's unceasing loyalty and commitment (Shakespeare). ${ }^{9}$ To be sure, Eliza Jane is no Guinevere. While she originates from the lowest station possible and has hardly risen in society after emancipation, her behavior-abiding loyalty, transparency and traditional sense of morality-shows the true meaning of the code of honor, in spite of the depravity of slavery she had endured. Unlike the nominal English medieval l'amour Courtois, by definition immoral and adulterous, Eliza Jane's natural loyalty is revealed using the subtlest of phrasings but which was actually devoid of characteristic attainment.

Like Arthur's relationship to Guinevere in Tennyson's The Coming of Arthur, Mr. Ryder may not care for Molly Dixon beyond her incomparable beauty and social status. At the ball—analogous to King Arthur's court-Chesnutt juxtaposes the two women, the living devout slave narrator Eliza Jane, akin in appearance to the "Loathly Lady" in Arthurian myth, but in fact a real phenomenon in American history, and then the wealthy and almost white Mrs. Dixon, suggestively personating the fictional Queen Guinevere in social standing. When Mr. Ryder asks the Blue Veins what he should do, to demonstrate her righteousness, Mrs. Molly Dixon proves that she is no Guinevere either: while shedding tears, she tells Mr. Ryder, as the first to speak up at the ball, that he should acknowledge Eliza Jane as his wife in a masterful public performance. ${ }^{10}$ Guinevere on the other hand, is depicted as jealous of other women appearing near her lover Lancelot such as Elaine, a

${ }^{9} \mathrm{Mr}$. Ryder is described as old enough to be Mrs. Molly's father, yet younger than his wife Eliza Jane. His swift change in ideology may be referenced by Merlin's comment on Arthur in The Coming of Arthur: "An old man's wit may wander ere he die" (Tennyson 24), which I suggest applies to old Mr. Ryder as well.

${ }^{10}$ Molly Dixon's approval of Mr. Ryder's remarriage to Eliza Jane also gives Mr. Ryder an out from her expectation of matrimony which the engagement ball was to publicly cement. Mr. Ryder had courted the widow, yet Mrs. Dixon's gracious conduct in acknowledging Eliza Jane also preserves Ryder's good reputation. 
character flaw unbecoming of a queen. Mrs. Molly Dixon accordingly admits Eliza Jane into the "courtly" world of their society, suggesting a kinship to a "sistah" who suffered a lowly fate through no fault of her own. In Ryder's court, his followers' nobility is ultimately secured by means of Socratic tutelage rather than Arthurian leadership. ${ }^{11}$

Robert Bone writes that the story's "theme has to do with the black man's sense of history. The wife of Mr. Ryder's youth is a symbol of his obligation of the past. The heritage of slavery is a painful one, and yet the old and ugly wife must be embraced" (Bone 99). Without an understanding of the underlying code of honor implicit in this story, Bone expresses reluctance to embrace the honorable choice with this remark. The unifying motif of Tennyson's disloyal Guinevere longing for Lancelot is a textual oeuvre readers of Chesnutt's time were familiar with, serving as the opposing foundation by which the conclusion of "The Wife of His Youth" becomes morally potent. The mutual circumstance the women share is their sterility: Guinevere provides no heir to Arthur, and Eliza Jane ironically usurps Mr. Ryder's earlier contention that "we must do the best we can for ourselves and those who follow us. Self-preservation is the first law of nature" (Chesnutt, Conjure 106) since no children would be forthcoming from the barren Eliza Jane. Nevertheless, to white readers who wish to put all negative consequences of slavery and the Civil War in the past, Mr. Ryder's remarriage in the end becomes an eloquent metaphor of national reconciliation by the mere fact that his reunification with Eliza Jane, the embodiment of African American post-war diasporic identity, provides a happy conclusion to the tragically common national phenomenon of African American separation caused by slavery and war.

${ }^{11}$ According to the philosophy of Immanuel Kant, "the harmony between natural impulses and the moral dimension of individual existence remains the fundamental good" of mankind (Vránková 92). 


\section{"Cicely's Dream"-Revision of the Forsaken Nurse}

As pointed out earlier, scholars have not placed Chesnutt's Civil War story under Tennyson's sphere of influence, though "Cicely's Dream" is deeply indebted to Idylls of the King and offers a layering of signification. The enslaved female protagonist, Cicely Green, registers as a figure of Arthurian romance. As I intend to illustrate, in Chesnutt's motivated revision of Tennyson, "Cicely's Dream" echoes the motif of a damsel's rescue of an injured combatant, her implicit expectation of matrimony after nursing him back to health, and the transformation of identity of the soldier which appear in Tennyson's idylls Enid and Geraint, Elaine and Lancelot and finally Gareth and Lynette.

Tennyson borrowed the plot of Enid and Geraint from the Mabinogion as well as Chrétien de Troyes' Eric et Eníde. Like Enid, Chesnutt's protagonist Cicely originates from humbler circumstances than the warrior she nurses back to health: she is a North Carolina plantation slave born around 1850. Tennyson's Enid's nurses her husband, the impervious Prince Geraint, shortly after combat with the followers of Limours:

And Enid heard the clashing of his fall,

Suddenly came, and at his side all pale

Dismounting loosed the fastenings of his arms,

Nor let her true hand falter, nor blue eye

Moisten, till she had lighted on his wound,

And tearing off her veil of faded silk

Had bared her forehead to the blistering sun

And swathed the hurt that drain'd her dear lord's life.

Then, after all was done that hand could do,

She rested, and her desolation came

Upon her, and she wept beside the way. (Tennyson 91)

Set in the spring of 1865 and the first years of the Reconstruction period, Chesnutt's story opens with a barefoot, attractive-looking, racially-mixed "maiden" whose worthy conduct resembles the behavior of Enid. While in the process of collecting vegetables and fruit in an Eden-like garden, Cicely hears a groan and discovers a wounded Union soldier unconscious with severe head injuries in the nearby pinewoods:

Upon the ground, under the shadow of the towering pines, a man lay at full length,- - a young man, several years under thirty [...] she saw the man was wounded and bleeding, and the nurse latent in all womankind awoke in her to the requirements of the situation $[\ldots]$ she took off her apron, dipped one end 
of it into the spring, and ran back to the wounded man. The apron was clean, and she squeezed a little stream of water from it into the man's mouth. He swallowed it with avidity [...] she bound the apron around his head as well as she could, and then sat down a moment on a fallen tree trunk, to think what she should do next. (Chesnutt, Conjure 172-173)

Parallels of aiding the wounded warrior by employing clothing and contemplating the process also include the women showing pity for the suffering soldiers. Finding the Union soldier just outside of the slave plantation property, the boundary of the plantation and the woods where slaves might escape, Cicely trespasses to the forbidden zone, probably risking punishment as she climbs over the fence to assist the stranger. Believing the soldier's color to be that of a lighter mulatto, Cicely surmises that the "negro" Union soldier fights to rescue his own people "to end the long night of their captivity" as slaves (King 102). However, this oblique figure is hard to place exactly. The ambivalence of the soldier's color is significant: he is not only aesthetically attractive, but seductively sensual. Consequently, he is assimilated into the slave community on the plantation. Chesnutt evocatively places the soldier's mental and physical recovery under Cicely's complete control, and his racialized otherness ironically transforms into Cicely's mode of perceiving her world so that his racial construct becomes black.

Both Enid and Cicely are keenly perceptive of the threats of enemies nearby and undertake measures to prevent adversaries from killing their warriors suffering from similar injuries. With the assistance of her grandmother Dinah, Cicely furtively conceals the unconscious "John," as they decide to call him, from the Confederates searching for the Union soldier: Cicely lays him on her bed in a shed for slaves. She offers him her natural untutored care, "the nurse latent in all womankind awoke in her to the requirement of the situation" (Chesnutt, Conjure 172). After deliberating, mother and daughter decide against informing their masters of his presence. ${ }^{12}$ In Enid and Geraint the same scene of defiance is played out. Enid hears threats and sees dangers that the helmet-wearing Geraint does not notice, so she cleverly disregards her

${ }^{12}$ Like Tennyson's poetry, Chesnutt's story moves to a picturesque setting. Cicely lives in the contraposition of the two worlds: her home is what appears like a paradise after the warrior's experiences on the battlefield: she brings him to her refuge and offers him peaceful shelter away from the chaos of combat. The depicted contrast in natural scenery is stark: With Dinah's assistance Cicely brings him out of a nearby dark pine forest, over the dividing fence, to a safely isolated clearing, consisting of a vegetable and fruit garden. 
vow of silence by warning him to the danger of the "brawny spearman" Earl Doorm. After falling from his horse and appearing dead, Geraint is "waken'd from his swoon" (Tennyson 93) much like the Union soldier who "opened his eyes and stared blankly [...]. Suddenly he essayed to put his hand to his head, gave a deep groan, and fell back again unconscious" (Chesnutt, Conjure 175). Both warriors require scrupulous care from their respective nurses, though Enid helps her husband while Cicely treats a complete stranger, acting out of a deep sense of moral obligation.

Prince Geraint had become obsessively jealous of attention she received from men so Enid had been commanded to be silent; he was made weary because of various rumors regarding Guinevere and Lancelot, aggressively making Enid suffer for another woman's transgressions. Hence his oath to service as a knight of chivalry has gone awry. In Chesnutt's story, the role-playing of silence is inverted: Union soldier "John" is dumb, his severe brain injury renders him speechless and he suffers from total amnesia. Over the course of a year, Cicely not only nurses him back to health, but teaches him to speak her vernacular. She reviews school lessons from various subjects she mastered every evening with him after attending the freedman school set up for former slaves. "John" loves Cicely: "His love for Cicely appeared the only thing for which he needed no suggestion." (Chesnutt, Conjure 181) Due to his head injury, he appears utterly innocent and completely guileless, unusual given his status as a combat soldier.

The unidentified warrior motif in "Cicely's Dream" also echoes the portrait of Gareth in Gareth and Lynette. The man charged by King Arthur to rescue the imprisoned maiden is identified as a kitchen worker. Lynette insists instead that the most celebrated knight, Lancelot, rescue her mistress, with the implicit understanding that Lady Lyonors would marry her champion. Instead of a knight of high lineage, Lynette dolefully gets escorted by a belle inconnu, a fair unknown "kitchen-knave" as King Arthur's choice to defeat the four outlaws holding Lady Lyonors imprisoned in her own castle.

The silent Unionist "John" is not so fair-skinned and otherwise unidentifiable. Reasoning that he is a light-skinned mulatto soldier, Cicely senses that she has found her dream-man. Once again, Chesnutt reverses Tennyson: while "dishwasher" and "kitchen-knave" Gareth (son of King Lot and Queen Morgause, King Arthur's half-sister) marries Lady Lyonors once he removes his "mask" and his true noble bloodlines are revealed, John's identity is only transformed after regaining his memory. Like the newly revealed high-born knight, the res- 
cued Union soldier is revealed to be a white man from Massachusetts named "Arthur" who had narrowly escaped a Confederate Prison at Salisbury. ${ }^{13}$ The virile characteristics of courage and how he overcame life-threatening dangers are evident only near the end of Chesnutt's plot. Arthur Carey is identified by name at the graduation ceremony by his betrothed, Martha Chandler, the schoolmistress from Massachusetts teaching Cicely and other former black slave children. Arthur Carey's amnesia functions as Chesnutt's literary contrivance for the kitchen-worker "mask" of the blue-blooded Gareth. Both characters are belle inconnu to their respective ladies, but in Chesnutt's reversal, the unhappy ending for Cicely keeps the color line "intact" while in the Arthurian rescue ending in marriage, the nominal high lineage is maintained for both families. Neglect of a woman's expectations is also evident in Arthur Carey (alias "John") after he forsakes Cicely Green: Arthur never thanks her for her bravery, her long-term nursing nor for mentoring him to speak and read. While she undertakes more effort in the recovery of her warrior's health than Enid, Cicely is forgotten immediately after Arthur recognizes Mayflower descendant ${ }^{14}$ Martha Chandler at the graduation exercises.

In a similar way, Lancelot and Elaine is noticeably reclaimed by Chesnutt as well. Unmarried and less than half the age of Lancelot, Elaine (along with her father Bernard, the Lord of Astolat) assist Lancelot before and after a jousting tournament. Elaine stood "rapt on his face as if it were god's" while Lancelot "had not dream'd she was so beautiful" (Tennyson 146). In spite of wearing her pearl and scarlet on his sleeve meant to help disguise himself, Lancelot believes that he has not provided the lovesick girl with an expectation of marital guarantee. On the contrary, Lancelot is merely fond of Elaine and certainly appreciates how she nurses his wounds. Unsurprisingly in courtly provisos, Lancelot was indeed fighting for the Maid of Astolat's honor in the unmistakably public forum of a tournament when he wore her pearls. Elaine nursed his multiple injuries (which Lancelot received in her honor), bringing him back to full vigor and potency. Yet after her perception of Lancelot's courtly behavior indicates a fulfillment of her marital expectations, Lancelot shatters all of her hopes.

${ }^{13}$ Historically, the notorious Salisbury Confederate Prison in North Carolina, classified as a kind of "miniature Andersonville," held thousands of captured Union soldiers who died of illness or starved to death.

${ }^{14}$ Like First Families of Virginia (FFV) for Southerners, among Northerners a Mayflower descendant remains to this day an American version of an aristocrat. 
Appearing as an unspoiled child of nature, Cicely Green likewise presumes "John" will marry her and fulfill her titular dream: they were already engaged and their wedding had been arranged to take place one week after her graduation. Like "the lily maid" Elaine, Cicely feels an idolatrous passion for "her" courageous warrior, with Cicely concealing her lover not only initially from Confederate soldiers, but later, after the war, from other women:

For a time Cicely kept him away, as much as possible, from others, because she did not wish them to see that there was anything wrong with him. This was her motive at first, but after a while she kept him to herself simply because she was happier so. He was hers-hers alone. She had found him, as Pharaoh's daughter had found Moses in the bulrushes: she had taught him to speak, to think, to love. (Chesnutt, Conjure 178)

While the crucial healing of the inflicted injuries takes place, both plots present a pastoral isolation of the nurse and warrior. Unlike the maidens in Tennyson's Idylls, Cicely dominates over her warrior in his surroundings, showing less than purely humane but also selfish motives. However, the dreams of Elaine and Cicely are disappointed due to the perceived social duty of their seductively handsome patients. The reaction to this disappointment by Elaine is transformed: Chesnutt's Cicely is disappointed but emerges more mature. Tennyson's Elaine responds to her unfulfilled expectations with excessive emotional trauma: "but this night I dream'd / That I was all alone upon the flood, / And then I said, 'Now shall I have my will [marriage with Lancelot];' / And there I woke, but still the wish remain'd.” (Tennyson 162)

While the virgin Elaine rejects as intolerable Lancelot's offer of half of his realm overseas in lieu of an unwanted marriage, he likewise rejects her odd compromise for much less than marriage: to become his squire. Tennyson changes Malory's text where the sexually more forward Elaine offers to become Lancelot's paramour. As Aaron Heisler points out, "Tennyson's emendation is almost comically prophylactic, utterly impoverishing Elaine of sexual will" (Heisler 161). With unfulfilled expectations of romantic bliss, the moribund Elaine dies of an emotional fever, reinforcing the convention of female malaise. After bravely confronting head on the ordeal of Lancelot's nearly fatal injury with her successful nursing work, ${ }^{15}$ Elaine becomes utterly

${ }^{15}$ Elaine's and Cicely's desire for the permanence of a family following the nursing of a warrior not only thematically corresponds to medieval Arthurian mythology but also to fiction by modernist authors such as Hemingway in Farewell to Arms (1929) and to a lesser extent Ondaatje in The English Patient (1992). 
incapable of comprehending that matrimonial aspirations with Lancelot is unattainable.

As the title indicates, Chesnutt accentuates the dream motif: "[Cicely] had dreamed a beautiful dream [...] that in her dream she had found something, and that her happiness had been bound up with the thing she had found [...] she had tasted some great and novel happiness." (Chesnutt, Conjure 171) Yet by radically downplaying Elaine's melodramatic demise (with her farewell letter on parchment held in her dead hand while floating down a river), Chesnutt's more mature African American schoolgirl accepts with resignation that "her" Union soldier was a white man. While Elaine has a consoling father at her side, Cicely, given her bright color in contrast to the dark complexion of her mother Dinah, likely has an absent Southern white father. Moreover, crossing the color line in wedlock was legally unfeasible in North Carolina. Subjugated to the law of the color line which Cicely dare not cross, Chesnutt's story transforms Arthurian motifs into racial signifiers. Like Lancelot, Arthur Carey may be understood to behave justifiably but ignobly; neither of the spotless women were recognized as a marital prize to their respective knights.

Intertextually in this prose revision of the idyll Lancelot and Elaine, the narrator unpretentiously designates Cicely "the other woman," and like Elaine, an ineligible lover of what ends up becoming a short-lived relationship. Chesnutt's version of the forsaken nurse motif laconically concludes that "her beautiful dream had been one of the kind that go by contraries" (Chesnutt, Conjure 187). Chesnutt's witty allusion to "contraries" is recognizably targeted to Tennyson's well-documented predilection to poetically convey the contradictory dualistic nature of the universe, as Allan Danzig meticulously demonstrates in his article, "The Contraries: A Central Concept in Tennyson's Poetry." Included in Danzig's study of contraries are the early versions of the idylls published in 1859 subtitled "The True and the False" in which Enid, Elaine, Vivien and Guinevere are portrayed. Yet in revising via parody the courtly ideals of Arthurian myth in Tennyson, Chesnutt's story not only echoes Tennyson's "contraries" but succeeds in establishing likeness in unlikeness by vividly distinguishing Elaine's initial exasperation and fatal despair with Cicely's uncomplaining endurance which resonates consistently with Eliza Jane Taylor's astonishing perseverance, thereby undermining the validity of the traditional concept of honor through intertextual correlations of Tennyson's two true women, Enid and Elaine. 


\section{Conclusion}

I have situated Chesnutt's two stories in the Arthurian tradition inspired specifically by Tennyson's popular poetry in a sometimes-sarcastic tone against ideals of exclusiveness, discrimination and racial oppression. During Reconstruction, Southern whites particularly enjoyed reading the forsaken ideals and decline of King Arthur's court expressed in Tennyson's Idylls of the King, as many identified them with the "Lost Cause" myth of the Confederacy. Ideals such as the superiority of the white race, of the Arthurian ethos manifested in the medieval code of honor reframed against black people, were frequently misread into a Tennysonian support during and after Reconstruction for oppressive racist efforts of the $\mathrm{Ku} \mathrm{Klux} \mathrm{Klan}$, for instance in lines such as these:

For when the Romans left us, and their law,

Relax's its hold upon us, and the way:

Were filled with rapine, here and there a deed

Of prowess done redress'd a random wrong. (Tennyson 235)

In his journals, Chesnutt examined writers of influence among white Southerners and later employed similar tropes used by these authors in order to convey a different vision of the common weal. In the absorbing plot of "The Wife of His Youth," Mr. Ryder ultimately does not break his troth, in contrast to the broken faith presented in the Idylls of the King where desire tops duty. While Lancelot ignored his moral obligations by his affair with the king's wife, Mr. Ryder protects the rights of his wife Eliza Jane. In Chesnutt's contrasting of characters, Eliza Jane suffers for her husband much more than Enid or Elaine did for their knights. In Chesnutt's second story, Cicely avidly hopes to marry an unidentified wounded warrior she heals, coddles, loves, and even educates, so that she may fulfill her dream, but much like Elaine's desire for Lancelot, a previous relationship interferes, so she is likewise forsaken. After the recovering veteran recognizes his old sweet heart Martha Chandler, Arthur's response is reminiscent of Lancelot's rejection. Accordingly, white Northerners leave the South and return to the North, replicating the Union forces of occupation abandoning blacks of the South at the end of Reconstruction.

In his fiction Chesnutt thematically undermines patriarchal dimensions which Tennyson's "true women" motif underscores: neither Eliza Jane nor Cicely follow any passive stance but pursue their own righteous aspirations, though men ultimately determine matrimonial 
outcomes. Employing an elaborately intertextual strategy, Chesnutt repeats and then subverts the inefficacious chivalric tradition, loosely linking courtship in "Cicely's Dream" with the historical social uplift movement of blacks through Freedman School education during Reconstruction. Indeed, just as Chesnutt wrote in the aforementioned journal entry, an African American woman has educated and elevated a white man.

The concluding failure to fulfill the African American protagonists' sought-after love of white beauty closely binds "The Wife of His Youth" and "Cecily's Dream" intertextually to Tennyson's poetry. With a consistent ideology of white beauty in his idylls and other poetry in mind, Tennyson chose to exclude from among his Arthurian sources the plot of the Middle High German epic Parzival by Wolfram von Eschenbach where the hero's older African half-brother Feirefiz might have played a constructive, even universalizing, role in the plot of the idyll The Holy Grail:; ${ }^{16}$ instead, Tennyson merely engages Percival's white sister, a nun, in his version.

In his two daring reenactments of Tennyson, Charles W. Chesnutt implies that African Americans, whether living in the North or South, in a metropolis or in the province, whether old or young, dark or light, highly educated or simply an ambitious former slave, suffer, overcome hardships, love and moreover are as honorable, perchance at a higher level, than the legendary heroes of the Idylls of the King. Moreover, Chesnutt exposes the senselessness of the Arthurian Code and the time-honored racialized values. By highlighting the tenacity of Eliza Jane and the numerous skills in nursing and pedagogy of Cicely, it is especially Chesnutt's African American women who come off with a sense of agency showing that, in contrast to Tennyson's heroes, men may actually not be more enduringly virtuous than women.

\section{WORKS CITED}

Bone, Robert. Down Home: Origins of the Afro-American Short Story. New York, NY: Columbia University Press, 1998.

Chesnutt, Charles. W. The Journals of Charles W. Chesnutt. Ed. Richard Brodhead. Durham, NC: Duke University Press, 1993.

Chesnutt, Charles. W. Conjure Tales and Stories of the Color Line. New York, NY: Penguin Classics, 2000.

${ }^{16}$ For details regarding racial and religious tolerance in Wolfram's Parzival, see Classen. 
Classen, Albrecht. "Wolfram on Eschenbach's Encounters with the 'Others': Emergence of Toleration and Tolerance in the Early Thirteen Century." Toleration and Tolerance in Medieval and Early Modern European Literature. New York, NY: Routledge, 1998. 62-85.

Danzig, Allen. “The Contraries: A Central Concept in Tennyson's Poetry.” PMLA 77.5 (1962): 577-585.

Day, Aidan. Tennyson's Scepticism. London: Palgrave MacMillan, 2005.

Duncan, Charles. "Introduction." The Northern Stories of Charles W. Chesnutt. Athens, OH: Ohio University Press, 2004.

Gilbert, Elliot L. “The Female King: Tennyson’s Arthurian Apocalypse.” PMLA 98.5 (1983): 863-878.

Heisler, Aaron Yale. “The English Destiny of Tennyson's Camelot.” Philological Quarterly 88.1/2 (2009): 151-170.

King, Martin Luther. "I Have a Dream." I Have a Dream: Writings and Speeches That Changed the World. New York, NY: HarperOne, 1992 (1963). 101-107.

Lambdin, Laura. Camelot in the Nineteenth Century: Arthurian Characters in the Poems of Tennyson, Arnold, Morris and Swinburne. Westport, CT: Greenwood Press, 2000.

Maier, Angelica J. "Is Cleopatra Black? Examining Whiteness and the American New Woman." Humanities 68.10 (2021): 1-18.

Miller, J. Hillis. "The Limits of Pluralism III: The Critic as Host.” Critical Inquiry 3.3 (1977): 439-447.

Rosenberg, John D. “Tennyson and the Passing of Arthur." Victorian Poetry 25.3/4 (1987): 141-150.

Shakespeare, William. Hamlet, Prince of Denmark. New York, NY: Signet Classics, 1998 (c. 1601).

Simpson, Roger. Camelot Regained: The Arthurian Revival and Tennyson, 1800-1849. Wolfsboro, NH: Brewer, 1990.

Sollors, Werner. "Thematics Today." Thematics, Interdisciplinary Studies. Eds. Max Louwerse and Willie Van Peer. Amsterdam: John Benjamins, 2002. 217-236.

Tennyson, Alfred. Idylls of the King and a Selection of Poems. New York, NY: Signet Classics, 1961 (1888).

Tucker, Herbert F. "The Epic Plight of Troth in Idylls of the King.” ELH 53.3 (1991): 701-720.

Vránková, Kamila. Metamorphoses of the Sublime. České Budějovice: Jihočeská univerzita, 2019.

Wonham, Henry. Charles W. Chesnutt: A Study of the Short Fiction. New York, NY: Twayne Publishers, 1998. 


\section{Novo branje Lorda Alfreda Tennysona: Pogled od blizu na zgodbi »Žena njegove mladosti« in "Cecilijine sanje« Charlesa W. Chesnutta}

Ključne besede: angleška poezija / Tennyson, Alfred / afroameriška literatura / medbesedilnost / Chesnutt, Charles W. / legende o kralju Arthurju / viteštvo / dvorna ljubezen

Članek preučuje, kako se je revizije del znanega angleškega pesnika Lorda Alfreda Tennysona (1809-1892), ki je v verzih upesnil srednjeveško Arturjevo legendo (Idila kralja in druge pesmi), lotil afroameriški pisatelj Charles W. Chesnutt (1858-1932). Chesnuttova pripovedna zbirka Žena njegove mladosti in druge zgodbe iz barvne serije (1899) obravnava različne parametre v kontekstu posledic, ki jih je povzročilo suženjstvo, denimo estetske pojme lepote, vezane na kvaliteto belega in znotrajrasne neenakosti. Končni poraz protagonistov, moškega in ženske, pri uresničevanju njunih romantičnih prizadevanj, povezuje naslovno zgodbo zbirke z zgodbo »Cecilijine sanje«. Poleg tematike obarvanosti Chesnutta za sklicevanje na Tennysonovo poezijo motivirajo tudi trenutki, v katerih so idealizirani viteški kodeks časti, belost in nepopolna dvorska ljubezen. Tennysonove parabole nudijo Chesnuttu medbesedilno shemo, s pomočjo katere vključuje implicitnega bralca tako, da prenavlja, preoblikuje in tudi podreja motiv dvorske ljubezni v teh idiličnih arturskih legendah.

1.01 Izvirni znanstveni članek / Original scientific article

UDK 82.091

DOI: https://doi.org/10.3986/pkn.v44.i3.09 